\title{
Agricultural potential and soil use based on the pedogenetic properties of soils from the cerrado-caatinga transition
}

\section{Aptidão agrícola e uso do solo baseado nas propriedades pedogenéticas de solos da transição cerrado-caatinga}

\author{
Rafael Felippe Ratke ${ }^{1 *}$; Alcinei Ribeiro Campos²; Alberto Vasconcellos Inda ${ }^{3}$; \\ Ronny Sobreira Barbosa ${ }^{4}$; Yuri Jacques Agra Bezerra da Silva ${ }^{4}$; \\ Júlio César Azevedo Nóbrega ${ }^{5}$; João Batista Lopes da Silva ${ }^{6}$
}

\author{
Highlights: \\ Vertisols in a sedimentary basin in the southern region of Piauí. \\ Soil genesis in sedimentary basins. \\ Weathering in the soil formation process. \\ Physical and chemical properties of soil classes provide agricultural land use.
}

\begin{abstract}
The sustainable use of soil requires a broad knowledge of its genesis, morphology, properties, and distribution in the landscape. Thus, the objective of this study was to characterize the pedogenetic attributes of representative soils from the cerrado-caatinga transition of the Gurguéia river basin to indicate their agricultural potential and limitations for the implementation of agroforestry systems. National and international soil classification systems were used to define the soil classes. The limiting factors and agricultural potential were characterized following the evaluation system of the agricultural potential of Brazilian land. In general, profiles 1, 3, 5, and 6 had a low nutrient budget and a sandy to loam texture. Profiles 2, 4, and 7 showed high clay content and nutrient budget. The soil profiles were classified as Ustic Quartzipsamments, Udic Haplusterts, Xanthic Haplustox, Arenic Kanhaplustults, Typic Haplustox, and Aridic Dystrustept based on their pedogenetic characteristics. Udic Haplusterts and Arenic Kanhaplustults soils display restrictions regarding the planting of forests owing to oxygen and soil depth limitations. The other soil classes had adequate physical properties for the implementation of agricultural systems and pastures, including good drainage and medium texture; however, they had low natural fertility, and thus require technologies for soil acidity correction and fertilization. Ustic Quartzipsamments and Ustic soils require the implementation of conservation systems, such as agroforestry, to avoid degradation.
\end{abstract}

Key words: Soil classification. Geochemistry. Agroforestry Systems.

1 Prof., Universidade Federal de Mato Grosso do Sul, UFMS, Chapadão do Sul, MS, Brasil. E-mail: rafael.ratke@ufms.br

2 Dr. em Ciência do Solo, Programa de Pós-Graduação em Ciência do Solo, Universidade Federal do Rio Grande do Sul, UFRGS, Porto Alegre, RS, Brasil. E-mail: alcineicampos@gmail.com

3 Prof., Programa de Pós-Graduação em Ciência do Solo, UFRGS, Porto Alegre, RS, Brasil. E-mail: alberto.inda@ufrgs.br

4 Profs., Universidade Federal do Piauí, UFPI, Campus Professora Cinobelina Elvas, Bom Jesus, PI, Brasil. E-mail: ronny. barbosa@ufpi.edu.br; yuri jacques@hotmail.com

5 Prof., Universidade Federal do Recôncavo da Bahia, UFSB, Cruz das Almas, BA, Brasil. E-mail: jcanobrega@gmail.com

6 Prof., Universidade Federal do Sul da Bahia, UFSB, Teixeira de Freitas, BA, Brasil. E-mail: silvajbl@yahoo.com.br

* Author for correspondence 


\section{Resumo}

O uso do solo de forma sustentável requer um amplo conhecimento sobre sua gênese, morfologia, propriedades e distribuição na paisagem. Dessa forma, objetivou-se com esta pesquisa realizar a caracterização pedogenética dos solos representativos da transição cerrado-caatinga da bacia hidrográfica do rio Gurguéia a fim de indicar sua aptidão e limitações para a implantação de sistemas agroflorestais. A caracterização baseou-se no estudo morfológico e na análise química e física dos horizontes de sete perfis de solos. Os sistemas de classificação de solos nacional e internacional foram utilizados para definir as classes de solos existentes na área pesquisada. Os fatores limitantes e a aptidão agrícola dos solos foram caracterizados conforme preposto no sistema de avaliação da aptidão agrícola de terras do Brasil. De forma geral, os perfis 1, 3, 5 e 6 apresentam baixa reserva de nutrientes e textura arenosa a média. Os perfis 2, 4 e 7 possuem maiores teores de argila e maior reserva de nutriente. Diante das características pedogenéticas dos perfis, pôde-se classificar os perfis de solo como NEOSSOLO QUARTZARÊNICO Órtico latossólico; VERTISSOLO HIDROMÓRFICO Órtico típico, LATOSSOLO AMARELO Distrófico típico, ARGISSOLO AMARELO Distrófico Abrúptico, LATOSSOLO VERMELHOAMARELO Distrófico argissólico e CAMBISSOLO HÁPLICO Tb Eutrófico típico respectivamente. Os VERTISSOLOS e CAMBISSOLOS presentam restrições a implantação de florestas devido à restrição de oxigênio e restrição a profundidade do solo. As demais classes de solos apresentaram propriedades físicas adequadas para a implantação de sistemas agrícolas e pastagens, incluindo boa drenagem e textura média; no entanto, tinham baixa fertilidade natural e, portanto, requerem correção da acidez do solo e adubação. Os solos NEOSSOLOS e ARGISSOLOS requerem a implementação de sistemas de conservação, como as agroflorestas, para evitar sua degradação.

Palavras-chave: Classificação do solo. Geoquímica. Sistemas agroflorestais.

\section{Introduction}

Soils formed in the tropics are among the oldest in the world (International Union of Soil Science [IUSS], 2014). The factors managing soil formation vary in time and space (Deckers, Nachtergaele, \& Spaargaren, 2003); therefore, soils in any ecosystem display variability (Hartemink \& Bockheim, 2013) with several characteristics that are reflected in different ecological features (Pietrasiak et al., 2013). These characteristics, which can be observed by studying the horizons of the soil profiles (Hartemink \& Bockheim, 2013) help manage soil during the natural control of elemental and chemical transport to the atmosphere, hydrosphere, and biosphere (Kabata-Pendias, 2011) and the natural cycles of chemical elements, solar absorption, radiation, and water storage (Soares, Alves, Linhares, Egreja, \& Fontes, 2017). The sustainability of production systems in different biomes worldwide is questionable owing to the diversity of environments (Bloomfield et al., 2018). The compilation of this information allows the classification of soils, which supports more rational land use planning (Mosleh et al., 2017), given that soil plays a crucial role in ecosystem functionality (Adhikari \& Hartemink, 2016).

Tropical biomes are highlighted in this context, among them the Brazilian caatinga-cerrado. The Caatinga, which is usually naturally composed of small trees and shrubs that are tolerant to the semiarid climate of this biome (Sampaio \& Silva, 2005), has an area of $844,453 \mathrm{~km}^{2}$, representing $10 \%$ of the Brazilian territory (Santos, Leal, Almeida-Cortez, Fernandes, \& Tabarelli, 2011). The Cerrado is the second largest Brazilian biome, occupying 2 million $\mathrm{km}^{2}$, which represents $23 \%$ of the national territory (Souza, 2007). In the Cerrado biome, there is a higher concentration of rainfall than that in the Caatinga, which creates vegetation patterns similar to those found in the savannas (Eiten, 1994). In the Gurguéia river basin, which is located in the state of Piauí, these two biomes blend, forming a natural complex of soils and landscapes that create a biodiversity hotspot (Myers, Mittermeier, Mittermeier, Fonseca, \& Kent, 2000). 
There has been an exponential growth of agricultural and pasture activities in the Gurguéia river basin recently (Companhia Nacional de Abastecimento [CONAB], 2016), which has occurred without the necessary prior knowledge of the pedogenetic characteristics of these soils. Jacomine (1986) undertook an exploratory survey of the soils of the southern region of Piaui and Pragana, Souza, Moura and Soares (2016) classified the highlands of this region. To fill this knowledge gap, the objective of the present study was to characterize the morphological, physical, chemical, and mineralogical attributes of soils representative of the cerrado-caatinga transition occurring in the Gurguéia river basin to better understand their genesis. In addition, this information was used to classify the soils and indicate their suitability and limitations for the implementation of agroforestry systems (AS).

\section{Materials and Methods}

\section{Study sites}

The Gurguéia watershed covers an area of $48,830 \mathrm{~km}^{2}\left(06^{\circ} 48^{\prime} 00^{\prime \prime}\right.$ to $10^{\circ} 52^{\prime} 00^{\prime \prime} \mathrm{S} ; 43^{\circ} 16^{\prime} 00^{\prime \prime}$ to $45^{\circ} 32^{\prime} 00^{\prime \prime} \mathrm{W}$ ) (Figure 1). The main watercourse has a length of $520 \mathrm{~km}$ and drains the entire southern end of the state of Piauí. The climate of the region is of the type Aw, based on the Köppen-Geiger classification system (Peel, Finlayson, \& McMahon, 2007), with an average annual temperature of 26 ${ }^{\circ} \mathrm{C}$ and an average annual rainfall ranging from 600 to $1300 \mathrm{~mm}$, with high concentrations from November to March (Silva, Medeiros, Santos, \& Gomes-Filho, 2013).
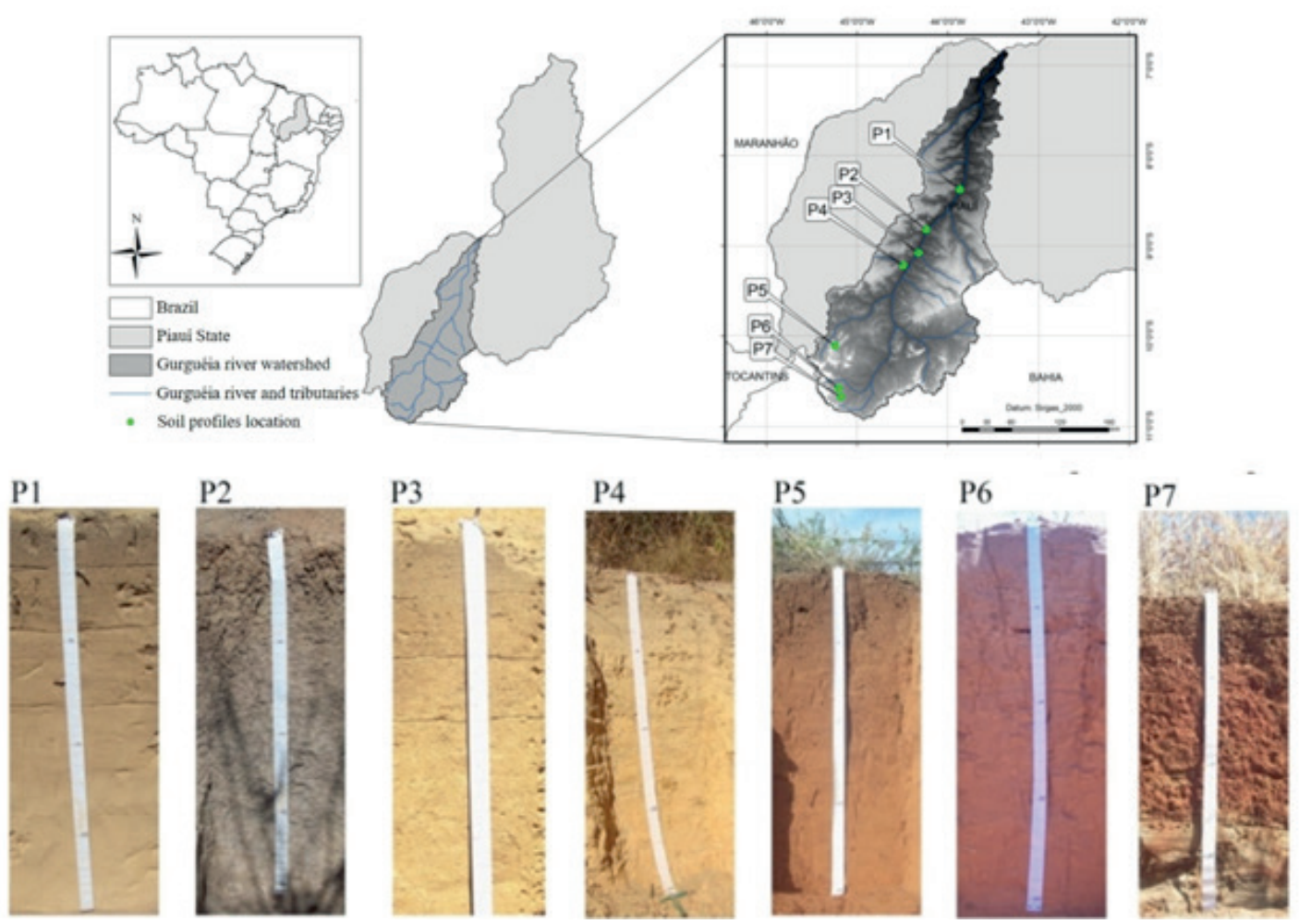

P1: Ustic Quartzipsamments - NEOSSOLO QUARTZARÊNICO Órtico latossólico; P2: Udic Haplusterts - VERTISSOLO HIDROMÓRFICO Órtico típico, P3: Xanthic Haplustox LATOSSOLO AMARELO Distrófico típico; P4: Arenic Kanhaplustults - ARGISSOLO AMARELO Distrófico Abrúptico; P5: Typic Haplustox - LATOSSOLO AMARELO Distrófico típico; P6: Typic Haplustox - LATOSSOLO VERMELHO-AMARELO Distrófico argissólico e P7: Aridic Dystrustept - CAMBISSOLO HÁPLICO Tb Eutrófico típico.

Figure 1. Location, distribution and image of studied soils. 
The vegetation is characterized by the formation oftropical savanna type, comprising forest, savannah, and country formations, which is characterized by a cerrado-caatinga ecotone. The basin consists of crystalline terrain and sediments from the Paraíba sedimentary basin (Secretaria de Recursos Hídricos do Ministério do Meio Ambiente [SRH], 2006). To obtain the best characterization, seven locations were selected along the watershed (Table 1) and from these, the soil profiles corresponding to the local pedon were collected and studied (Figure 1).

\section{Table 1}

Landscape characterization and parent material of the locations of the evaluated profiles

\begin{tabular}{|c|c|c|c|}
\hline Profiles & Site & Vegetation $^{1}$ & Parent Material $^{2}$ \\
\hline 1 & $\begin{array}{l}\text { Near the confluence of the Gurguéia river and } \\
\text { temporary Correia river with form of the plain. }\end{array}$ & $\begin{array}{c}\text { Transitional } \\
\text { Cerrado-Caatinga }\end{array}$ & Alluvial sediments \\
\hline 2 & $\begin{array}{l}\text { Approximately } 500 \mathrm{~m} \text { from the river Gurguéia } \\
\text { (west side), with a plain form. }\end{array}$ & $\begin{array}{l}\text { Secondary forest with } \\
\text { deciduous vegetation }\end{array}$ & Alluvial sediments \\
\hline 3 & $\begin{array}{l}\text { Out for inundation plain of the Gurguéia, } \\
\text { with a soft corrugated form }\end{array}$ & $\begin{array}{c}\text { Transitional } \\
\text { Cerrado-Caatinga } \\
\end{array}$ & $\begin{array}{l}\text { Longá Formation } \\
\text { Sandstone }\end{array}$ \\
\hline 4 & $\begin{array}{l}\text { Near for Quilombo hill, } \\
\text { with a soft corrugated form. }\end{array}$ & $\begin{array}{c}\text { Transitional } \\
\text { Cerrado-Caatinga }\end{array}$ & $\begin{array}{l}\text { Poti Formation } \\
\text { Sandstone }\end{array}$ \\
\hline 5 & Plateau & Cerrado & $\begin{array}{l}\text { Urucuia Formation } \\
\text { Sandstone }\end{array}$ \\
\hline 6 & Plateau & Cerrado & $\begin{array}{l}\text { Urucuia Formation } \\
\text { Sandstone }\end{array}$ \\
\hline 7 & Plateau with soft corrugated form & Cerrado & $\begin{array}{l}\text { Gneiss of the } \\
\text { Cristalândia complex }\end{array}$ \\
\hline
\end{tabular}

${ }^{1}$ Jacomine (1986); ${ }^{2}$ SRH (2006).

Morphological, Physical, chemical, and sulfuric attack analysis

In each profile, the horizons were identified and their morphological characteristics described based on the procedure by Santos, Santos, Ker, Anjos and Shimiz (2015). For laboratory analysis, samples of the superficial and subsurface horizons diagnosis were used.

Soil samples were dried, homogenized, and sieved through $2 \mathrm{~mm}$ mesh to obtain the air-dried thin earth fraction. Physical and chemical analyses were performed according to the methodology of Teixeira, Donagemma, Fontana and Teixeira (2017). Chemical analysis results were used to calculate the following variables: base saturation (V\%), Al saturation ( $\mathrm{m} \%)$, effective cation exchange capacity $(\mathrm{t})$, and potential cation exchange capacity $(\mathrm{T})$ of the soil. Sulfuric attack was performed to determine the levels expressed as iron oxide $\left(\mathrm{Fe}_{2} \mathrm{O}_{3}\right)$ and aluminum $\left(\mathrm{Al}_{2} \mathrm{O}_{3}\right)$, followed by alkaline dissolution to silicon oxide $\left(\mathrm{SiO}_{2}\right)$. After this characterization, the molecular relationships of $\mathrm{Ki}\left(\mathrm{SiO}_{2} / \mathrm{Al}_{2} \mathrm{O}_{3}\right)$ and $\mathrm{Kr}\left[\mathrm{SiO}_{2} /\left(\mathrm{Al}_{2} \mathrm{O}_{3}+\mathrm{Fe}_{2} \mathrm{O}_{3}\right)\right]$ were calculated (Teixeira et al., 2017).

\section{Soil classification and agricultural suitability}

The soils were classified according to Brazil's official soil classification taxonomic system [SiBCS] (Santos et al., 2018), soil survey from the United States of America (Soil Survey Staff [SSS], 2014), and the world reference base (IUSS, 2014). Evaluation of the degree of use limitation of the soil profiles of the Gurguéia watershed was performed 
by adopting the land suitability and availability assessment in Brazil (Ramalho-Filho \& Beek, 1995).

The factors used in the evaluation of land use limitation were fertility, water, and oxygen deficiencies; susceptibility to soil erosion; and impediments to mechanization, classifying them as null, low, moderate, strong, or very strong depending on the results of the pedogenetic soil profile assessments. Subsequently, the agricultural potential of the soils for the establishment of crops, pasture, and forestry was evaluated, as well as the viability of land use improvement, identifying that the classified soils require a low, medium, and/or high technological level to be managed.

\section{Results}

\section{Morphological characteristics}

Profile 1 had a sequence of horizons A-C deeper than $2.0 \mathrm{~m}$ and was yellow in color (10 YR) throughout the profile, with chroma expression between 4 and 7 and brightness levels ranging from 4 to 5 (Table 2). In profile 2, only the sequence of horizons A-B were present, with a depth greater than $2.0 \mathrm{~m}$ and a yellowish hue (10YR), with low brightness (4) and chroma (3 and 2). Profiles 3, 5 , and 6 , which were located on different plateaus (Table 1), showed the same sequence of horizons A-B, but with different soil color expressions. Profile 4 contained the sequence of horizons A-EB-C. The predominant color in profile 4 was a 10 YR yellowish hue. The transition between the $\mathrm{E}$ and $B$ horizons of this profile stood out for being flat and abrupt. Profile 7 contained the sequence of horizons A-B-C and a color of 2.5 YR hue (burnished to reddish), with a variation of one unit for value and two units for chroma, with this profile characterized as non-polychrome.

The profiles showed textural, structural, and consistency variations. The textural class varied from sandy loam to sand in profile 1 . Profile 2 contained the sandy silt class on horizon A and very clayey on horizon $\mathrm{B}$. The horizons of profiles 3,5 , and 6 were sand to sandy loam. The variations of the sand, loam, and clay textural classes occurred between the soil horizons of profile 4 . The clayey silt textural class predominated in the horizons of profile 7 .

A strong small granular and very small structure was observed in the horizons of profiles 1, 3, 4, 5 , and 6 . Profile 2 contained strong and mediumsized angular and prismatic blocks. In the horizons from profiles 3, 5, and 6, the soil structures showed variability, with very small to small granular structures, and strong and moderately strong angular and subangular blocks. The subangular structure with a strong degree and average size predominated in profile 4. In horizon B of profile 7, large angular and prismatic block structures with moderate and common clay-coated structure units were observed.

The soil of horizon A of profile 1 was soft, loose, no-plastic, and slightly sticky, and in horizon $\mathrm{AC}$ and $\mathrm{C}$ of this profile, the consistency changed to very friable. Profile 2 had horizons that were extremely hard and firm, as well as dry soils, which were very plastic and very sticky when wet. The horizon A profile of dry soil in profile 3 contained soft, friable, non-plastic, and slightly sticky soil; the soils with horizons $\mathrm{AB}$ and BA were slightly hard, friable, slightly, and slightly sticky; and the horizon $\mathrm{Bw}$ with a loose aspect. The soil consistency characteristics of the profile 3 horizon was similar to that of the soils of profiles 5 and 6 ; however, the degree of consistency varied from hard to slightly hard when dry, friable and very friable, non-plastic and slightly sticky.

The soils of profile 4 showed loose, very friable, non-plastic, and slightly sticky consistency for horizon A. For horizon E, this changed to hard and friable and for horizon $\mathrm{Bt}$ and $\mathrm{BC}$ it became very hard, firm, plastic, and slightly sticky. In profile 7, the consistency when dry was slightly hard for horizon A, hard for horizon B, and loose for horizon $\mathrm{C}$; when wet it varied from friable to very friable for all horizons. 
Table 2

Morphological description of the pedogenetic horizons of tropical soil profiles of the Brazilian cerrado-caatinga transition

\begin{tabular}{|c|c|c|c|c|c|}
\hline Horizon $^{(1)}$ & Layer $(\mathrm{m})$ & Color (moist) & Texture & Structure $^{(2)}$ & Transition $^{(3)}$ \\
\hline \multicolumn{6}{|c|}{ Profile 1} \\
\hline A & $0.00-0.18$ & $10 Y R 4 / 4$ & Sandy & w and vs gn & pl. and df. \\
\hline $\mathrm{C}$ & $0.18+$ & $10 \mathrm{YR} 5 / 6$ & Loam sandy & str and sm gn & pl. and df. \\
\hline \multicolumn{6}{|c|}{ Profile 2} \\
\hline Av & $0.00-0.25$ & $10 Y R 4 / 3$ & Loam silt & $\begin{array}{l}\text { str and md, abk and pris } \\
\text { (pres. of slickensides) }\end{array}$ & pl. and gd \\
\hline Bvg & $0.25+$ & $10 \mathrm{YR} 4 / 2$ & very clayey & vst, abk and pris & pl. and gd \\
\hline \multicolumn{6}{|c|}{ Profile 3} \\
\hline A & $0.00-0.10$ & $10 Y R 4 / 4$ & Loam sandy & md and sm, gn & pl. and df. \\
\hline $\mathrm{AB}$ & $0.10-0.45$ & $10 Y R 5 / 8$ & Loam sandy & md and sm, gn & pl. and df. \\
\hline $\mathrm{BA}$ & $0.45-0.80$ & $10 Y R 6 / 8$ & Loam sandy & md and sm, abk & pl. and df. \\
\hline $\mathrm{Bw}$ & $0.80+$ & 10YR6/8 & Loam sandy & wk and sm, abk & pl. and df. \\
\hline \multicolumn{6}{|c|}{ Profile 4} \\
\hline A & $0.00-0.40$ & $10 Y R 5 / 4$ & Sandy & wk and vs, gn and abk & pl. and df. \\
\hline $\mathrm{E}$ & $0.40-0.60$ & $10 Y R 5 / 6$ & Loam sandy & str and me, abk & pl. and ab. \\
\hline $\mathrm{Bt} 1$ & $0.60-0.90$ & $10 Y R 5 / 6$ & Loam clayey sand & str and sm, sbk & pl. and df. \\
\hline $\mathrm{Bt} 2$ & $0.90-1.00$ & $10 Y R 6 / 8$ & Loam clayey & str and me, sbk & pl. and df. \\
\hline $\mathrm{BC}$ & $1.00+$ & $10 \mathrm{YR} 6 / 8$ & clayey & str and $s=m e, s b k$ & pl. and df. \\
\hline \multicolumn{6}{|c|}{ Profile 5} \\
\hline $\mathrm{A}$ & $0.00-0.28$ & 7,5YR4/4 & Loam sandy & str and vs, gn & pl. and df. \\
\hline $\mathrm{AB}$ & $0.28-0.50$ & $5 \mathrm{YR} 4 / 6$ & Loam sandy & str and vs, gn & pl. and df. \\
\hline $\mathrm{BA}$ & $0.50-0.67$ & $5 \mathrm{YR} 4 / 7$ & Loam sandy & str and vs, gn & pl. and df. \\
\hline $\mathrm{Bw}$ & $0.67+$ & $5 \mathrm{YR} 4 / 6$ & Loam clayey sand & str and vs, abk & pl. and df. \\
\hline \multicolumn{6}{|c|}{ Profile 6} \\
\hline $\mathrm{A}$ & $0.00-0.10$ & $5 Y R 7 / 6$ & Loam sandy & str and vs, gn & pl. and df. \\
\hline $\mathrm{AB}$ & $0.10-0.25$ & 7,5YR4/6 & Loam sandy & str and vs, gn & pl. and df. \\
\hline $\mathrm{BA}$ & $0.25-0.50$ & $5 \mathrm{YR} 4 / 6$ & Loam sandy & str and vs, gn & pl. and df. \\
\hline $\mathrm{Bw}$ & $0.50+$ & $2,5 \mathrm{YR} 4 / 8$ & Loam clayey sand & str and vs, abk & pl. and df. \\
\hline \multicolumn{6}{|c|}{ Profile 7} \\
\hline A & $0.00-0.20$ & $2,5 \mathrm{YR} 3 / 4$ & Clayey sandy & md and sm, gn & pl. and gd \\
\hline $\mathrm{AB}$ & $0.20-0.40$ & $2,5 \mathrm{YR} 4 / 6$ & Clayey sandy & md and sm, sbk & pl. and gd \\
\hline $\mathrm{BA}$ & $0.40-0.55$ & $2,5 \mathrm{YR} 3 / 4$ & Clayey sandy & md and me, sbk & pl. and gd \\
\hline $\mathrm{Bi}$ & $0.55-1.00$ & $2,5 \mathrm{YR} 3 / 4$ & Clayey sandy & $\begin{array}{l}\text { str and bg, sbk and pris, } \\
\text { cc common }\end{array}$ & pl. and clear \\
\hline $\mathrm{BC}$ & $1.00-1.20$ & $2,5 \mathrm{YR} 3 / 4$ & Clayey sandy & str and bg, sbk and pris & pl. and clear \\
\hline $\mathrm{C}$ & $1.20+$ & - & - & - & - \\
\hline
\end{tabular}

${ }^{(1)}$ Nomenclature of the horizons according to the SiBSC (Santos et al., 2018); (2)ang = angular; bl = blocks; abk = angular block; $\mathrm{sbk}=$ subangular blocks; pris = prismatic; $\mathrm{str}=$ strong; $\mathrm{vst}=$ very strong; $\mathrm{wk}=$ weak; $\mathrm{md}=$ moderate; $\mathrm{gn}=$ granular; $\mathrm{sm}=\mathrm{small}$; $\mathrm{vs}=$ very small $\mathrm{vf}=$ very fine; $\mathrm{bg}=\mathrm{big} ; \mathrm{me}=$ medium; $\mathrm{cc}=$ clay coated; ${ }^{(3)} \mathrm{ab}=\mathrm{abrupt} ; \mathrm{df}=\mathrm{difuse} ; \mathrm{gd}=$ gradual. 


\section{Physical and chemical attributes}

Most soil profiles contained horizons with a predominance of the sand fraction $\left(>590 \mathrm{~g} \mathrm{~kg}^{-1}\right)$ and low clay levels $\left(<350 \mathrm{~g} \mathrm{~kg}^{-1}\right)$, except for profiles 2 and 7 that showed clay levels higher than $400 \mathrm{~g} \mathrm{~kg}^{-1}$ (Table 3). Soil organic matter (SOM) content can

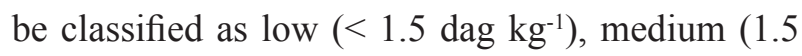

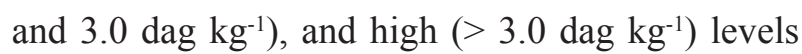
(Sobral, Barreto, Silva, \& Anjos, 2015). Thus, the soils of horizon A of profiles 1, 5, and 6 had low concentrations of SOM. Horizon A in profiles 2, 3, 4 , and 7 had average SOM concentrations. The soils of the subsurface horizons of the profiles had low SOM contents.

Profiles 1, 3, 5, and 6 had $\mathrm{pH}$ values in water that were equal to or lower than 5.1, characterizing strongly acidic soils based on SiBCS (Santos et al., 2018). Profile 4, with $\mathrm{pH}$ values between 5.1 and 5.6, had an intermediate reaction between moderately and strongly acidic, whereas profiles 2 and 7 showed a moderately acid reaction, with $\mathrm{pH}$ values between 5.9 and 6.0 (Table 3). The levels of bases and aluminum were very low, equal to or less than $1.5 \mathrm{cmol}_{\mathrm{c}} \mathrm{kg}^{-1}$ in most horizons of profiles $1,4,5$, and 6 , these soils had low $\mathrm{T}\left(<5.0 \mathrm{cmol}_{\mathrm{c}}\right.$ $\mathrm{dm}^{-3}$ ) (Sobral et al., 2015). However, the soils of profile 7 showed a medium $\mathrm{T}\left(5.0-15.0 \mathrm{cmol}_{\mathrm{c}} \mathrm{dm}^{-3}\right)$, whereas the soils of profile 2 had a high $\mathrm{T}(>15.0$ $\left.\mathrm{cmol}_{\mathrm{c}} \mathrm{dm}^{-3}\right)$. The horizons of profile 2 had Ki values above 3 and $\mathrm{Kr}$ values above 0.75 , indicating the presence of 2:1 clay. In this context, the horizon B from profile 2 showed a moderately high activity of the clay fraction $\left(>27 \mathrm{cmol}_{\mathrm{c}} \mathrm{kg}^{-1}\right.$ and $<40 \mathrm{cmol}_{\mathrm{c}} \mathrm{kg}^{-}$ $\left.{ }^{1}\right)$ (Santos et al., 2018). The average activity of the clay fraction $\left(>17 \mathrm{cmol}_{\mathrm{c}} \mathrm{kg}^{-1}\right.$ and $<27 \mathrm{cmol}_{\mathrm{c}} \mathrm{kg}^{-1}$ ) was verified in soil profile 7 . Soil profiles $3,4,5,6$, and 7 showed low activity of the clay fraction. Soil profiles $1,3,4,5$, and 6 showed low natural fertility, which was expressed by low base saturation values $(\mathrm{V} \%<50)$, whereas profiles 2 and 7 had high $\mathrm{V} \%$ values $(>50)$. 


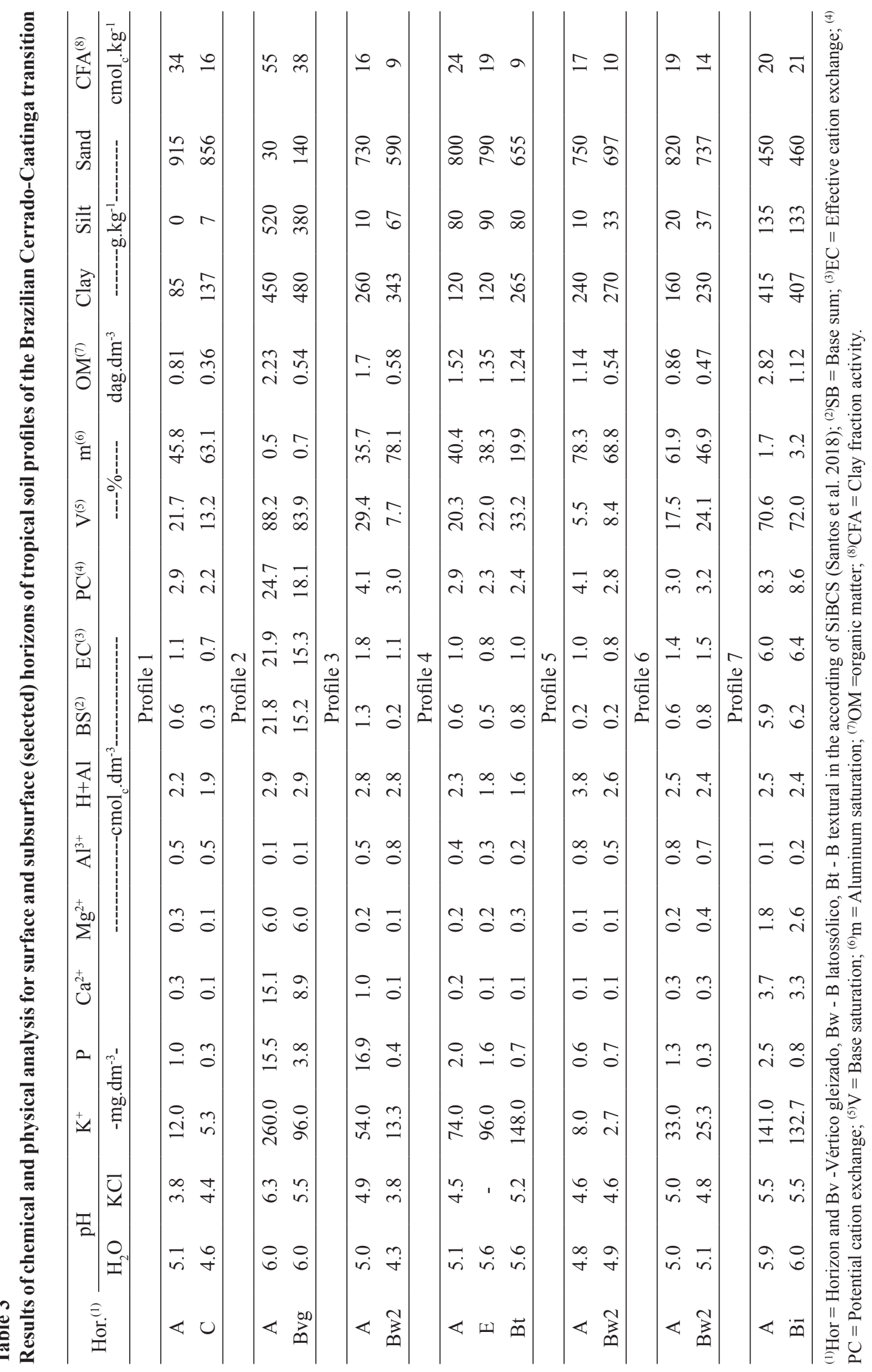


Elemental analysis and weathering

The colloidal fraction of the studied soils was mainly structured by silicon oxides $\left(\mathrm{SiO}_{2}\right)$, considering their higher concentration in most profiles compared to other oxides (Table 4). Additionally, $\mathrm{Al}_{2} \mathrm{O}_{3}$ and $\mathrm{Fe}_{2} \mathrm{O}_{3}$ levels showed increases with depth in all profiles. The highest values of these attributes were found in profiles
2 and 7, the same profiles that had higher clay contents (Table 3). Profiles 3, 5, and 6 had a high degree of weathering and the other profiles had soils with a low degree of weathering in their formation, highlighting profiles 2 and 7 because they had higher Ki values (Medeiros, Nascimento, Inda, \& Silva, 2013).

Table 4

Results of the analyzes by sulfuric attack in the dry soil for surface and subsurface (selected) horizons of tropical soil profiles of the Brazilian cerrado-caatinga transition

\begin{tabular}{|c|c|c|c|c|c|c|c|c|c|}
\hline \multirow{2}{*}{ Profile } & \multirow{2}{*}{ Horizon } & $\mathrm{SiO}_{2}$ & $\mathrm{Al}_{2} \mathrm{O}_{3}$ & $\mathrm{Fe}_{2} \mathrm{O}_{3}$ & $\mathrm{TiO}_{2}$ & $\mathrm{P}_{2} \mathrm{O}_{5}$ & \multirow{2}{*}{$\mathrm{Ki}^{(1)}$} & \multirow{2}{*}{$\mathrm{Kr}^{(2)}$} & \multirow{2}{*}{$\mathrm{Al}_{2} \mathrm{O}_{3} / \mathrm{Fe}_{2} \mathrm{O}_{3}$} \\
\hline & & \multicolumn{5}{|c|}{ 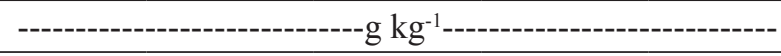 } & & & \\
\hline \multirow{2}{*}{1} & A & 2.59 & 3.07 & 0.60 & 0.14 & 0.00 & 1.43 & 1.27 & 8.01 \\
\hline & $\mathrm{C}$ & 5.11 & 5.11 & 1.10 & 0.31 & 0.00 & 1.70 & 1.49 & 7.28 \\
\hline \multirow{2}{*}{2} & A & 26.93 & 12.25 & 6.06 & 0.61 & 0.05 & 3.74 & 2.84 & 3.18 \\
\hline & $\mathrm{Bv}$ & 25.13 & 16.49 & 5.74 & 0.66 & 0.04 & 2.59 & 2.12 & 4.51 \\
\hline \multirow{2}{*}{3} & A & 7.57 & 5.89 & 1.71 & 0.35 & 0.01 & 2.19 & 1.84 & 5.42 \\
\hline & $\mathrm{Bw}$ & 14.41 & 11.81 & 2.99 & 0.68 & 0.01 & 2.07 & 1.79 & 6.21 \\
\hline \multirow{3}{*}{4} & $\mathrm{~A}$ & 4.35 & 2.81 & 0.80 & 0.22 & 0.01 & 2.63 & 2.22 & 5.51 \\
\hline & E & 5.19 & 3.58 & 0.80 & 0.26 & 0.00 & 2.47 & 2.16 & 7.01 \\
\hline & $\mathrm{Bt}$ & 12.44 & 9.22 & 2.27 & 0.50 & 0.01 & 2.29 & 1.98 & 6.37 \\
\hline \multirow{2}{*}{5} & A & 7.52 & 6.57 & 5.36 & 0.70 & 0.00 & 1.95 & 1.28 & 1.93 \\
\hline & $\mathrm{Bw}$ & 10.19 & 10.20 & 6.74 & 1.01 & 0.00 & 1.70 & 1.19 & 2.38 \\
\hline \multirow{2}{*}{6} & $\mathrm{~A}$ & 4.25 & 3.32 & 1.30 & 0.27 & 0.01 & 2.17 & 1.74 & 4.00 \\
\hline & $\mathrm{Bw}$ & 8.47 & 6.44 & 2.02 & 0.35 & 0.00 & 2.20 & 1.86 & 5.00 \\
\hline \multirow{2}{*}{7} & $\mathrm{~A}$ & 13.95 & 8.65 & 8.22 & 1.59 & 0.03 & 2.74 & 1.71 & 1.65 \\
\hline & $\mathrm{Bi}$ & 22.28 & 15.32 & 13.65 & 1.88 & 0.03 & 2.47 & 1.58 & 1.76 \\
\hline
\end{tabular}

(1) $\mathrm{Ki}=\mathrm{SiO}_{2} / \mathrm{Al}_{2} \mathrm{O}_{3}{ }^{(2)} \mathrm{Kr}=\mathrm{SiO}_{2} /\left(\mathrm{Al}_{2} \mathrm{O}_{3}+\mathrm{Fe}_{2} \mathrm{O}_{3}\right)$.

Soil classification and agricultural suitability

In profile 1 , the absence of a subsurface diagnostic horizon defined the soil in the order of NEOSSOLOS (Santos et al., 2018), equivalent to Entisols class (SSS, 2014) and Arenosols (IUSS, 2014) (Table 5). Use of this soil is limited because of its low natural fertility and high susceptibility to erosion (Table 6). This soil is suitable for agricultural crops, with pasture and forest restricted owing to the low technological level for management.
Horizon B of profile 2 was diagnosed visually as being of the order VERTISOLOS (Santos et al., 2018) (Table 5), equivalent to Vertisols (SSS, 2014) and Vertisols (IUSS, 2014). Profile 2 had strong oxygen limitation and was extremely strong to prevent mechanization; however, it had high natural fertility and slight water restriction, presenting agricultural suitability for natural pasture (Table 6).

Profiles 3, 5, and 6 had several similar and defining characteristics of the oxisols subsurface B horizon, 
which is a diagnosis of the order LATOSSOLO (Santos et al., 2018), equivalent to Oxisols (SSS, 2014) and Ferrasols (IUSS, 2014). These soils have agricultural suitability for agricultural cultivation, pasture, and forests with a high technological level owing to low natural fertility restrictions (Table 6).

Table 5

Soil Classification of tropical soil profiles of the Brazilian cerrado-caatinga transition

\begin{tabular}{|c|c|c|c|}
\hline Profile & $\mathrm{SiBCS}^{(1)}$ & Soil Survey Staff( ${ }^{(2)}$ & $\mathrm{WRB}^{(3)}$ \\
\hline 1 & $\begin{array}{l}\text { NEOSSOLO QUARTZARÊNICO Órtico } \\
\text { latossólico - Rqo }\end{array}$ & Ustic Quartzipsamments & Ribic Dystric Arenosol \\
\hline 2 & $\begin{array}{c}\text { VERTISSOLO HIDROMÓRFICO Órtico } \\
\text { típico - Vgo }\end{array}$ & Udic Haplusterts & Anthraquic Haplic Vertisol \\
\hline 3 & $\begin{array}{c}\text { LATOSSOLO AMARELO Distrófico } \\
\text { típico - Lad }\end{array}$ & Xanthic Haplustox & Xanthic Haplic Ferrasol \\
\hline 4 & $\begin{array}{l}\text { ARGISSOLO AMARELO Distrófico } \\
\text { abrúptico - Pad }\end{array}$ & Arenic Kanhaplustults & Abruptic Xanthic Lixisol \\
\hline 5 & $\begin{array}{l}\text { LATOSSOLO AMARELO Distrófico } \\
\text { típico - Lad }\end{array}$ & Typic Haplustox & Xanthic Haplic Ferrasol \\
\hline 6 & $\begin{array}{l}\text { LATOSSOLO VERMELHO-AMARELO } \\
\text { Distrófico argissólico - LVAd }\end{array}$ & Typic Haplustox & Xanthic Haplic Ferrasol \\
\hline 7 & $\begin{array}{l}\text { CAMBISSOLO HÁPLICO Tb Eutrófico } \\
\text { típico - Cxbe }\end{array}$ & Aridic Dystrustept & Rhodic Eutric Cambisol \\
\hline
\end{tabular}

${ }^{(1)} \mathrm{SiBCS}=$ Brazilian Soil Classification System (Santos et al., 2018); ${ }^{\left({ }^{2}\right)}$ Soil Survey Staff (SSS, 2014); ${ }^{(3)}$ WRB = World Reference Base for Soil Resources (IUSS, 2014).

Table 6

Degree of limitation and classification of the agricultural aptitude soil profiles of the Brazilian cerrado-caatinga transition

\begin{tabular}{cccccccc}
\hline \multirow{2}{*}{ Profile } & \multirow{2}{*}{ SiBCS $^{(1)}$} & \multicolumn{7}{c}{ Degree of Limitation ${ }^{(2)}$} & \multirow{2}{*}{ LSAA $^{(3)}$} \\
\cline { 3 - 6 } & & FD & AD & OD & SE & IM & \\
\hline 1 & RQo & VS & MS & NL & M & NL & 2'(a)bC \\
2 & VGo & NL & L & F & NL & VS & $5 \mathrm{~N}$ \\
3 & LAd & S & M & NL & M & NL & 1'(a)bC \\
4 & PAd & L & L & NL & VS & L & $4 \mathrm{P}$ \\
5 & LAd & S & M & NL & N & NL & 1'(a)bC \\
6 & LVAd & S & M & NL & L & NL & $1^{\prime}(\mathrm{a}) \mathrm{bC}$ \\
7 & CXbe & NL & L & NL & L & MS & $5 \mathrm{~N}(\mathrm{~s})$ \\
\hline
\end{tabular}

${ }^{(1)} \mathrm{SiBCS}=$ acronyms of soil classes according to the Brazilian Soil Classification System (H. G. Santos et al., 2018); ${ }^{(2)}$ Limitation Degree: $\mathrm{FD}=$ Fertility Deficiency, $\mathrm{AD}=$ Water Deficiency, $\mathrm{OD}=$ Oxygen Deficiency, $\mathrm{SE}=$ Susceptibility to erosion, $\mathrm{IM}=$ impediment to mechanization; ${ }^{(3)}$ LSAA = land suitability and availability assessment in Brazil (Ramalho \& Beek, 1995); NL = null; $\mathrm{L}=$ light; $\mathrm{M}=$ Moderate; $\mathrm{S}=$ Strong; $\mathrm{MS}=$ moderate strong; $\mathrm{VS}=$ Very strong; $\mathrm{a}, \mathrm{b}, \mathrm{c}=\mathrm{crop}$, pasture and forestry; $\mathrm{N}=$ natural pasture; $\mathrm{P}=$ cultivated pasture; Upper caser = good suitability, Lowercase letter = regular suitability, Lowercase letter in parentheses = restricted ability, and Absence of letter = inapt as used for identified soils of low medium and or high technological level to be manage. 
Profile 4, owing to the naming of its subsurface diagnostic horizon as textural $\mathrm{B}$, was classified as ARGISSOLO (Santos et al., 2018), equivalent to Ultisols (SSS, 2014) and Lixisols (IUSS, 2014). Profile 7 had the most distinct characteristics. The occurrence of an incipient subsurface diagnostic horizon B defined its classification in the order CAMBISSOLOS (Santos et al., 2018), equivalent to Inceptsols (SSS, 2014) and Cambisol (IUSS, 2014). Profile 7 represents a soil with high agricultural potential; however, it should be used with reservations, especially when its use is directed to the implantation of species with very deep root systems or that are very sensitive to gas exchange limitations. Thus, this soil has agricultural potential for the cultivation of natural pasture and is restricted for use with forestry regardless of the technological level adopted for its management (Table 6).

\section{Discussion}

Profile 1 contained the highest proportion of sand owing to its origin being associated with alluvial deposits of sandstone sediments of the Longá geological formation (Serviço Geológico do Brasil [CPRM], 2006). Profiles 3, 5, and 6 had a sandyloam texture, owing to the weathering of the original sedimentary rock (Formation Cabeça and Poti). Thus, profiles 3, 5, and 6 showed signs of advanced weathering, a well-developed structure, and an apparent lack of differentiation between horizons in response to color homogeneity throughout the profiles. Soil color indicated that profiles 3, 5, and 6 were formed under oxidative conditions; however, profile 3 appeared to have been formed under higher humidity conditions, followed by profiles 5 and 6, respectively. Cruz et al. (2018) found similar behavior when studying the soils of Cerrado Piauiense that were also located at the top of the landscape. This made it possible to identify the Haplustox diagnostic horizon $\mathrm{B}(\mathrm{Bw})$ in profiles 3, 5 , and 6 (Santos et al., 2018). The color of profiles 1 , 3 , and 4 was classified from the color classification as being the $10 \mathrm{YR}$ hue, owing to the hydrolysis of the primary minerals forming the goethite, which is a function of the tropical environment that occurs in this region (Vodyanitskii, Kirillova, Manakhov, \& Karpukhin, 2018).

However, in profile 4, the transition between horizons $\mathrm{E}$ and $\mathrm{B}$ stood out for being flat and abrupt. Thus, considering that horizon B contained more than twice the clay content of that found in horizon A, this horizon was identified as the textural diagnostic horizon $\mathrm{B}(\mathrm{Bt})$ and was classified as Arenic Kanhaplustults (SSS, 2014). Ki values below 1 have predominate oxides, whereas $\mathrm{Ki}$ values between 1 and 2 indicate kaolinite dominance, and values between 2 and 3 indicate kaolinite and 2:1 minerals (M. R. Soares, Alleoni, Vidal-Torrado, $\&$ Cooper, 2005). Therefore, none of the profiles had a predominance of oxides in the mineralogy of the evaluated soil profiles. The calculated $\mathrm{Kr}$ values suggest the predominance of kaolinite in all evaluated profiles, owing to the kaolinitic soils having $\mathrm{Kr}>0.75$ and oxidic soils $\mathrm{Kr}<0.75$ (Matias, Marques-Júnior, Siqueira, \& Pereira, 2013). The soil of profile 2 had $\mathrm{Ki}$ values above 3.00 and $\mathrm{Kr}$ values above 0.75 , indicating the presence of $2: 1$ clay. Therefore, the horizon B of profile 2 showed a moderately high activity of the clay fraction, reinforcing the presence of 2:1 clay in this soil.

Due to the morphological and chemical-physical characteristics of the soils, profiles 1, 3, 4, and 6 had a low $\mathrm{T}$ indicating their low natural fertility (Tang, Zeng, Nourbakhsh, \& Shen, 2009) and referring to the number of negative ground charges. These, in turn, may be $\mathrm{pH}$-dependent (SOM) or permanent (some clay minerals). In profiles 1, 5, and 6, using this attribute, besides having low levels of OM, they had a low amount of permanent load. Thus, the material had high soil acidity, with high Al, which can be toxic to plants and limit plant nutrition by other nutrients (Singh et al., 2017). The source material and degree of weathering were also responsible in profiles $1,3,4,5$, and 6 for providing them with low natural fertility, considering that low 
base concentration occurred $(\mathrm{V} \%<50)$. The soils of profiles $1,3,4,5$, and 6 had acidity that impaired the nutrition and development of crops and requires correctives to be added such as limestone (Goulding, 2016).

Profiles 1, 3, 4, 5, and 6 had similar morphological characteristics as a function of the source material (sedimentary rocks) and distinct physicochemical attributes in these soils. Because of these distinctions, profiles 1, 3, 4, 5, and 6 were classified as Ustic Quartzipsamments, Xanthic Haplustox, Arenic Kanhaplustults and Typic Haplustox according to soil survey (SSS, 2014).

The use of these more weathered soil profiles is limited by their low natural fertility and susceptibility to erosion. Thus, for the cultivation of the soils in profiles $1,3,4,5$, and 6 , technology methods must be used to increase fertility and conservation management must decrease the erosive potential of the soil. The Ustic Quartzipsamments and Haplustox are favorable to agricultural mechanization because there are no impediments to soil management owing to the physical characteristics of these soils. Among all studied profiles, these were the ones that had better conditions for the implementation of AS because they are deep, well-structured soils (Delarmelinda et al., 2014). However, excessive dispersion of soil particles by mechanization should be avoided and terraces should be constructed to prevent erosion.

The Arenic Kanhaplustults (profile 4) presents agricultural suitability for planted pasture (Delarmelinda et al., 2014). However, forestry pasture is the most appropriate because it requires only soil tillage for implementation, disadvantaging the erosive process (Silveira Franco et al., 2002). Loss, Pereira, Schultz, Anjos and Silva (2009) verified the better physical quality for Arenic Kanhaplustults with cultivation in AS than that of monoculture. AS can increase the contribution of $\mathrm{OM}$ in Ustic Quartzipsamments (Frouxe et al., 2011) regenerated areas, conventional agriculture and pasture was evaluated at Alto Ribeira Valley region, São Paulo State, Brazil. This contribution favors the improvement of the physical and chemical attributes of the soil, reducing soil and nutrient loss from the erosive process (Mendes et al., 2009). Thus, the implementation of conservationist systems is important for maintaining the sustainability of Arenic Kanhaplustults, Ustic Quartzipsamments and Haplustox.

Profile 2 had the highest clay concentration, with a low textural relationship. This was explained by its position in the floodplain in relation to the river, which may have favored the deposition of lighter materials, leading to the formation of clay soils, and thus promoting its grayish color. According to Rabenhorst, Matovich, Rossi and Fenstermacher (2014), a gray color indicates the steady presence of water during soil formation. The possible presence of iron oxides may also be responsible for the best aggregation on the horizon Bvg (Duiker, Rhoton, Torrent, Smeck, \& La, 2003). This moisture condition may hinder the neogenesis of 1:1 phyllosilicates and possibly led to the reduction of smectites iron that, despite having a bluish-green color, assume a gray color after the reduction of iron present in them (Vodyanitskii et al., 2018).

The occurrence of microrelief (Gilgai) was observed in profile 2, resulting from the expansion and contraction processes of soil mass (Coelho, Cortez, \& Olszevski, 2012). Considering these morphological characteristics, together with the granulometric characteristics, the subsurface horizon of profile 2 was identified as Gleissolic vertex B (Bvg) and was classified as Udic Haplusterts (SSS, 2014).

The soil composition of profile 7 reflects the source material and the processes associated with its transformation. The soil was derived from gneisses supplied by the Archean-age Cristalândia do Piauí complex (Pfaltzgraff, Torres, \& Brandão, 2010). The main minerals that form gneiss are mica and amphibole, as well as quartz and feldspar (Menezes, 
2013). In profile 7, the occurrence of hematite in the clay fraction also directly interfered with the particle aggregation process (Duiker et al., 2003). This interference probably drove the flocculation and is expressed in the subangular, angular, and prismatic blocks with a strong development in the Bi horizon. In addition, common wax with a moderate degree in the structural units of horizon $\mathrm{Bi}$ was found. The placement as incipient diagnostic horizon $\mathrm{B}(\mathrm{Bi})$ was based on the characteristic of this soil having T close to $17 \mathrm{cmol}_{\mathrm{c}} \mathrm{kg}^{-1}$ of clay and more than $4 \%$ changeable minerals, a high $\mathrm{Ki}$ molecular ratio of 2.2, thickness less than $0.50 \mathrm{~m}$, and the presence of saprolite. Horizon Bi oriented to classify profle 7 as Aridic Dystrustept (SSS, 2014).

Profiles 2 and 7 had V values $>50 \%$. Profile 2 was associated with the clay sediments from the areas occupied by gneiss of the Cristalândia Complex. This same material was responsible for providing the characteristics of profile 7 .

The evaluated soils showed the occurrence of phyllosilicates in the clay fraction and the increase in the depth of $\mathrm{SiO}_{2}$ values is explained by the increase in the clay fraction concentration (Schiavo, Pereira, Miranda, Dias_Neto, \& Fontana, 2010). Profile 2 was formed by alluvial deposits of clay sediments from the upstream areas (profile 7), where gneiss rocks occur that contain mica and feldspar. Mica and feldspar minerals contain the elements $\mathrm{Al}, \mathrm{K}, \mathrm{Ca}, \mathrm{Mg}, \mathrm{Si}$, and Fe. Mica is a clay mineral (Coringa, Couto, Perez, \& Torrado, 2012); therefore, the derivative of these minerals can form primary clay minerals such as kaolinite and secondary as gypsite and hematite (Christofoletti \& Moreno, 2015). In a hydromorphic environment, as occurred in profile 2, gleization processes were common, and thus the formed material may have expansive clays (Coringa et al., 2012). The periodic flooding regime and the source material, alluvial sediments, promoted the mineralogical, physical, and chemical characteristics of profile 2 soil. Due to the limitations of profiles 2 and 7 soil, they are suitable only for natural pasture and restricted for implantation to AS. Froufe, Rachwal and Seoane (2011) reported that, depending on the crops used, for both agricultural and forestry, Aridic Dystrustept did not restrict the use of AS. However, its physical characteristics must be considered, related to the trampling of the soil that can cause compaction (Coelho et al., 2012), as well as the humidity regime, due to its expansiveness, which can cause damage to the roots during soil contraction. Profile 2 soil does not favor the use of agricultural mechanization, owing to its high clay content, which during the dry period becomes very resistant and abrasive, and during the humid period becomes very sticky, thus preventing equipment from satisfactorily turning the soil. Additionally, possible flooding due to being in the lower part of the relief makes a lack of oxygen possible (Delarmelinda et al., 2014).

Aridic Dystrustept are considered to have a low degree of weathering and good natural fertility (Medeiros et al., 2013). The presence of saprolite in horizons $\mathrm{B}$ and $\mathrm{C}$ at $2 \mathrm{~m}$ depth may negatively influence the development of forest species that have deep root systems. However, this does not prevent the use of this soil as natural pasture and planted forestry, and its high natural fertility can contribute to maintaining productive forage for grazing animals. Therefore, the Aridic Dystrustept of profile 7 was classified as suitable for natural pasture and restricted for planted forestry.

\section{Conclusion}

The limiting characteristics of oxygen deficiency and effective depth in Ustic Quartzipsamments and Aridic Dystrustept prevent the use of these as AS, especially for planted forests. The AS is the most sustainable way to utilize the other soils studied. In profiles 1 and 4 , the implementation of soil conservation systems is required, such as the AS, as there is a great possibility of soil loss due to erosion in these profiles because of their physical characteristics. 


\section{Acknowledgements}

For Universidade Federal de Mato Grosso do Sul; For Coordenação de Aperfeiçoamento de Pessoal de Nível Superior - Brasil (CAPES) - Finance Code 001. The National Program for Academic Cooperation (PROCAD -CAPES - NF 21/2009), a partnership between the Postgraduate Program in Agronomy - Soils and Plant Nutrition of the Universidade Federal do Piauí and the Postgraduate Program in Soil Science of the Universidade Federal de Lavras that enabled this research to be carried out.

\section{References}

Adhikari, K., \& Hartemink, A. E. (2016). Linking soils to ecosystem services - A global review. Geoderma, 262, 101-111. doi:10.1016/j.geoderma.2015.08.009

Bloomfield, G., Bucht, K., Martínez-Hernández, J. C., Ramírez-Soto, A. F., Sheseña-Hernández, I., LucioPalacio, C. R., \& Ruelas Inzunza, E. (2018). Capacity building to advance the United Nations sustainable development goals: An overview of tools and approaches related to sustainable land management. Journal of Sustainable Forestry, 37(2), 157-177. doi: 10.1080/10549811.2017.1359097

Christofoletti, S. R., \& Moreno, M. M. T. (2015). Comparação tecnológica, mineralógica e química da Formação Corumbataí em dois polos cerâmicos distintos visando sua aplicação na indústria de revestimentos cerâmicos. Cerâmica, 61(360), 469476. doi: 10.1590/0366-69132015613601951

Coelho, D. S., Cortez, J. W., \& Olszevski, N. (2012). Variabilidade espacial da resistência mecânica à penetração em vertissolo cultivado com manga no perímetro irrigado de Mandacaru, Juazeiro, Bahia, Brasil. Revista Brasileira de Ciência do Solo, 36(3), 755-764. doi: 10.1590/S0100-06832012000300007

Companhia Nacional de Abastecimento. (2016). Acompanhamento da safra brasileira de grãos, safra 2015/2016, décimo segundo levantamento. Brasília: CONAB. Retrieved December 1, 2018, from https:// www.conab.gov.br/info-agro/safras/graos

Coringa, E. D. A. O., Couto, E. G., Perez, X. L. O., \& Torrado, P. V. (2012). Atributos de solos hidromórficos no Pantanal Norte Matogrossense. Acta Amazonica, 42(1), 19-28. Retrieved from http:// www.scielo.br/scielo.php?script $=$ sci_arttext\&pid $=$ S0044-59672012000100003
Cruz, N., Barbosa, R., Moura, M., Teixeira, D., MarquesJúnior, J., \& Silva, J. (2018). Color parameters applied to pedotransfer functions in the estimation of soil attributes. Semina: Ciências Agrárias, 39(4), 477-1488. doi: 10.5433/1679-0359.2018v39n $4 \mathrm{p} 1477$

Deckers, J., Nachtergaele, F., \& Spaargaren, O. (2003). Tropical soils in the classification systems of USDA, FAO and WRB. In: G. Stoops (Ed.), Evolution of tropical soil science: past and future. Brussels: Royal Academy of Overseas Sciences (pp. 79-94).

Delarmelinda, E. A., Wadt, P. G. S., Anjos, L. H. C., Masutti, C. S. M., Silva, Ê. F., Silva, M. B., Coelho, R. M., Silva, L. M., Shimizu, S. H., Couto, W. H. (2014). Aplicação de Sistemas de Avaliação da Aptidão Agrícola das Terras em Solos do Estado do Acre, Amazônia. Biota Amazônia, 4(2), 87-95. doi: 10.18561/2179-5746/biotaamazonia.v4n2p87-95

Duiker, S., Rhoton, F., Torrent, J., Smeck, N., \& La, R. (2003). Iron (hydr)oxide crystallinity effects on soil aggregation. Soil Science Society of America Journal, 67(2), 606-611. doi: 10.2136/sssaj2003.6060

Eiten, G. (1994). Vegetação do Cerrado. In: M. N. Pinto. (Ed.), Cerrado: Caracterizção, Ocupação e Perspectivas (pp. 9-65). Brasília: UnB-Sematec.

Froufe, L. C. M., Rachwal, M. F. G., \& Seoane, C. E. S. (2011). Potencial de sistemas agroflorestais multiestrata para sequestro de carbono em áreas de ocorrência de Floresta Atlântica. Pesquisa Florestal Brasileira, 31(66), 143-154. doi: 10.4336/2011. pfb.31.66.143

Goulding, K. W. T. (2016). Soil acidification and the importance of liming agricultural soils with particular reference to the United Kingdom. Soil Use and Management, 32(3), 390-399. doi: 10.1111/ sum. 12270

Hartemink, A. E., \& Bockheim, J. G. (2013). Soil genesis and classification. CATENA, 104, 251-256. 10.1016/j.catena.2012.12.001

International Union of Soil Science (IUSS). (2014). International soil classification system for naming soils and creating legends for soil maps. World Reference Base for Soil Resources 2014, update 2015 (Vol. World Soil). Roma: FAO. doi: 10.1017/ S0014479706394902

Jacomine, P. K. T. (1986). Levantamento exploratório reconhecimento de solos do Estado do Piauí. Rio de Janeiro: Embrapa Solos.

Kabata-Pendias, A. (2011). Trace Elements in soil and Plants. Boca Raton: Fourth CRC Press. 
Loss, A., Pereira, M. G., Schultz, N., Anjos, L. H. C. dos, \& Silva, E. M. R. da. (2009). Atributos químicos e físicos de um Argissolo Vermelho-Amarelo em sistema integrado de produção agroecológica. Pesquisa Agropecuaria Brasileira, 44(1), 68-75. doi: 10.1590/S0100-204X2009000100010

Matias, S.S.R., Marques-Júnior, J., Siqueira, D.S., \& Pereira, G. (2013). Modelos de paisagem e susceptibilidade magnética na identificação e caracterização do solo. Pesquisa Agropecuária Tropical, 43(1), 93-103. doi: 10.1590/S198340632013000100003

Medeiros, P. S.C. de, Nascimento, P. C. do, Inda, A. V., \& Silva, D. S. da. (2013). Caracterização e classificação de solos graníticos em topossequência na região Sul do Brasil. Ciência Rural, 43(7), 1210-1217. doi: 10.1590/S0103-84782013000700011

Mendes, I. de C., Hungria, M., Reis-Junior, F. B., Fernandes, M. F., Chaer, G. M., Mercante, F. M., \& Zilli, J. É. (2009). Bioindicadores para Avaliação da Qualidade dos Solos Tropicais: utopia ou realidade? (Documentos). Planaltina: Embrapa Cerrados.

Menezes, S. de O. (2013). Rochas: manual fácil de estudo e classificação. São Paulo: Oficina de Textos.

Mosleh, Z., Salehi, M. H., Amini Fasakhodi, A., Jafari, A., Mehnatkesh, A., \& Esfandiarpoor Borujeni, I. (2017). Sustainable allocation of agricultural lands and water resources using suitability analysis and mathematical multi-objective programming. Geoderma, 303, 5259. doi: 10.1016/j.geoderma.2017.05.015

Myers, N., Mittermeier, R. A., Mittermeier, C. G., da Fonseca, G. A. B., \& Kent, J. (2000). Biodiversity hotspots for conservation priorities. Nature, 403(6772), 853-858. doi 10.1038/35002501

Peel, M. C., Finlayson, B. L., \& McMahon, T. A. (2007). Updated world map of the Köppen-Geiger climate classification. Hydrology and Earth System Sciences, 11(5), 1633-1644. doi: 10.5194/hess-11-1633-2007

Pfaltzgraff, P., Torres, F. S. de M., \& Brandão, R. de L. (2010). Geodiversidade do Estado do Piauí. Recife: CPRM. Retrieve from http://rigeo.cprm.gov.br/ xmlui/handle/doc/16772

Pietrasiak, N., Regus, J. U., Johansen, J. R., Lam, D., Sachs, J. L., \& Santiago, L. S. (2013). Biological soil crust community types differ in key ecological functions. Soil Biology and Biochemistry, 65, 168171. doi: 10.1016/j.soilbio.2013.05.011

Pragana, R., Souza, V. Jr., Moura, R., \& Soares, J. (2016). Caracterização de Latossolos amarelos da serra do quilombo no cerrado Piauiense. Caatinga, 29(4), 832-840. doi: 10.1590/1983-21252016v29n407rc
Rabenhorst, M., Matovich, M., Rossi, A., \& Fenstermacher, D. (2014). Visual assessment and interpolation of low chroma soil colors. Soil Science Society of America Journal, 78(2), 567-570. doi: 10.2136/sssaj2013.08.0347

Ramalho-Filho, A., \& Beek, K. J. (1995). Sistema de avaliação da aptidão agrícola das terras. Rio de Janeiro: Embrapa Solos.

Sampaio, E. V. S. B., \& Silva, G. C. (2005). Biomass equations for Brazilian semiarid caatinga plants. Acta Botanica Brasilica, 19(4), 935-943. doi: 10.1590/ S0102-33062005000400028

Santos, H G, Jacomine, P. K. T., Anjos, L. H. C., Oliveira, V. A., Lumbreras, J. F., Coelho, M. G., Almeida, J. A., Araújo-Filho, J., Oliveira, J. B., Cunha, T. (2018). Sistema brasileiro de classificação de solos -SiBCS (5a ed.). Rio de Janeiro: Embrapa.

Santos, J. C., Leal, I. R., Almeida-Cortez, J. S., Fernandes, G. W., \& Tabarelli, M. (2011). Caatinga: the scientific negligence experienced by a dry tropical forest. Tropical Conservation Science, 4(3), 276-286. doi: 10.1177/194008291100400306

Santos, R., Santos, H., Ker, J., Anjos, L., \& Shimizu, S. (2015). Manual de descrição e coleta de solo no campo (7th ed.). Viçosa: SBCS.

Schiavo, J. A., Pereira, M. G., Miranda, L. P. M., Dias Neto, A. H., \& Fontana, A. (2010). Caracterização e classificação de solos desenvolvidos de arenitos da formação Aquidauana-MS. Revista Brasileira de Ciência Do Solo, 34(3), 881-889. doi: 10.1590/ S0100-06832010000300029

Secretaria de Recursos Hídricos do Ministério do Meio Ambiente. (2006). Caderno da região hidrográfica do Parnaíba. Brasília, SRH. Retrieved from http:// www.mma.gov.br/estruturas/161/_publicacao/161_ publicacao03032011023605.pdf.

Serviço Geológico do Brasil. (2006). Mapa Geológico do Estado do Piauí, 1:1.000.000. Retrieved from http:// www.cprm.gov.br/publique/media/mapa_piaui.pdf

Silva, V., Medeiros, R., Santos, D., \& Gomes-Filho, M. (2013). Variabilidade pluviométrica entre regimes diferenciados de precipitação no estado do Piauí. Revista Brasileira de Geografia e Física, 6(5), 14631475. doi: 10.26848/rbgf.v6.5.p1463-1475

Silveira Franco, F., Couto, L., Carvalho, A. F., Jucksch, I., Fernandes-Filho, E., Silva, E., Meira-Neto, J. A.A. (2002). Evaluation of Erosion Under Agroforestry and Conventional Systems in Zona Da Mata De Minas Gerais. Revista Árvore, 26(6), 751-760. doi: 10.1590/S0100-67622002000600011 
Singh, S., Tripathi, D. K., Singh, S., Sharma, S., Dubey, N. K., Chauhan, D. K., \& Vaculík, M. (2017). Toxicity of aluminium on various levels of plant cells and organism: A review. Environmental and Experimental Botany, 137, 177-193. doi: 10.1016/j. envexpbot.2017.01.005

Soares, L. C., Alves, J. O., Linhares, L. A., Egreja Filho, F. B., \& Fontes, M. P. F. (2017). Vulnerability of tropical soils to heavy metals: A PLS-DA classification model for Lead. Microchemical Journal, 133, 258-264. doi: 10.1016/j.microc.2017.03.028

Soares, M. R., Alleoni, L. R. F., Vidal-Torrado, P., \& Cooper, M. (2005). Mineralogy and ion exchange properties of the particle size fractions of some Brazilian soils in tropical humid areas. Geoderma, 125(3-4), 355-367. doi: 10.1016/j. geoderma.2004.09.008

Sobral, L. F., Barreto, M. C. V., Silva, A. J., \& Anjos, J. L. (2015). Guia Prático para Interpretação de Resultados de Análises de Solo. Embrapa Tabuleiros Costeiros-Documentos (INFOTECA-E). Aracaju: Embrapa Tabuleiros Costeiros.
Soil Survey Staff. (2014). Keys to Soil Taxonom (12th ed.). Washington: USDA-Natural Resources Conservation Service.

Souza, L. F. (2007). Recursos vegetais usados na medicina tradicional do Cerrado (comunidade de Baús, Acorizal, MT, Brasil). Revista Brasileira de Plantas Medicinais, 9(4), 44-54.

Tang, L., Zeng, G., Nourbakhsh, F., \& Shen, G. (2009). Artificial neural network approach for predicting cation exchange capacity in soil based on physicochemical properties. Environmental Engineering Science, 26(1), 137-146. doi: 10.1089/ees.2007.0238

Teixeira, P. C., Donagemma, G. K., Fontana, A., \& Teixeira, W. G. (2017). Manual de métodos de análises de solos (3a ed.). Brasília: Embrapa.

Vodyanitskii, Y., Kirillova, N., Manakhov, D., \& Karpukhin, M. (2018). Iron Compounds and the Color of Soils in the Sakhalin Island. Eurasian Soil Science, 51(2), 163-175. doi: 10.1134/ s1064229318020138 